\title{
Hydrochemical evaluation of bottled mineral waters and spring at Corumbataí city, São Paulo State, Brazil
}

\author{
D. M. Bonotto \& B. W. Tessari \\ Departamento de Petrologia e Metalogenia, \\ Instituto de Geociências e Ciências Exatas-UNESP, Rio Claro, Brazil
}

\begin{abstract}
This investigation was carried out within São Paulo State, Brazil, and involved the sampling of well-known mineral bottled waters for performing a comparative hydrochemical study and of a spring occurring at Corumbataí city, in order to evaluate its suitability for bottling. Several methods were utilized for acquiring the hydrochemical data like the methyl orange end-point titration, potentiometry, ion selective electrode, colorimetry, flame photometry and inductively-coupled plasma spectrometry. The results obtained for the analyzed samples were compared with the guideline values established by the National Commission of Rules and Standards for Food of the Brazilian Health Ministry published in 1976. The Brazilian Code for Mineral Waters that was established by Register 7841 published on 8 August 1945 was also taken into account for verifying if the spring waters are mineralized. The hydrochemical data allowed identify some constituents impoverishing the water quality, thus, implying on its nonutilization for commercial purposes (bottling). In one specific case, the spring water only can become appropriate for human consumption after previous chemical treatment.

Keywords: drinking water quality, spring waters, hydrochemistry, mineral waters, bottling, contamination.
\end{abstract}

\section{Introduction}

In many countries, spring waters have been extensively used for consumption purposes as an option to tap water, as many people believe they are healthy and/or can be utilized for health cures. Additionally, economic reasons have also 
favored their use as bottled waters so that the commercialization of mineral waters has widely increased.

The thermal and mineral waters use in Brazil is not recent due to arrival of European immigrants, mainly from Portugal. The following facts have been reported by [1]: thermal waters occurrence in Caldas Velhas (Goiás State) in 1722; knowledge in 1766 of the therapeutic properties of Araxá waters (Minas Gerais State); discovery in 1813 of Caldas da Imperatriz waters (Santa Catarina State); knowledge between 1834 and 1875 of the waters of Cambuquira, São Lourenço, Lambari and Caxambu (Minas Gerais State); realization in 1888 by the Imperial Government of the chemical analysis of Águas Salutaris (Rio de Janeiro). Additionally, it was pointed out by [2] the realization of studies in 1786 for a better understanding of the Poços de Caldas waters (Minas Gerais State), whereas the investigation of Manoel da Silveira Rodrigues in 1832 about the thermal waters of Poços de Caldas, Pocinhos do Rio Verde and Lambari (Minas Gerais State) was reported by [3].

The physician Pedro Sanches de Lemos arrived in 1873 at Poços de Caldas city (Nossa Senhora da Saúde das Águas de Caldas District by that time). He travelled to Europe in 1901 with the aim of getting information about the building of a spa there [4]. He was the first to describe in 1907 the question about radioactivity in mineral waters in Brazil during the VI Brazilian Congress of Medicine and Surgery [5].

The physician Francisco Tozzi focused in 1913 the waters of Águas de Lindóia (São Paulo State) in a conference realized at the National Academy of Medicine, suggesting that all mineral waters, mainly thermal, act by the radioactivity effect [4]. The thorium and radium emanation in thermal springs of Caldas da Imperatriz (Santa Catarina State) was also evaluated by [6].

The thermal spas were gradationally constructed in Brazil for therapeutic and leisure purposes, corresponding the time elapsed between the 1930s and 1950s to the most auspicious hydrothermal period in the country [7]. The Brazilian Code for Mineral Waters (BCMW) was established in this epoch, under French influence, by Register 7841 published on 8 August 1945 [8]. This rule is still in force, having focused the mineral waters for spas and bottling uses, as well the potable waters for bottling [4].

In Brazil, the production and commercialization of mineral waters is managed by the National Department of Mineral Production (DNPM). Traditionally, the mineral waters had been used or directly consumed in the springs, where touristic centers developed around. However, in the present days, the mineral water for consumption is distributed in vessels for ingestion distant from the springs, whereas hydrothermal spas for therapeutic baths and leisure exhibit infra-structure with hotels and many facilities for users.

The first available information about the production of bottled mineral waters in Brazil dates back 1911 [9]. Only Minas Gerais and Rio de Janeiro States had industries by that time, whose annual production was 1,420,000 L (Minas Gerais- 1,220,000 L; Rio de Janeiro- 200,000 L) [9]. However, an accentuated expansion of the national production occurred in the period between 1996 and 2007 , i.e. North region-386\%, West Central region-287\%, South region-207\%, 
Northeastern region-130\% and Southeastern region-127\% [9]. The Southeastern region in 2007 was responsible by about $48 \%$ of the national production of mineral and potable water, the highest in the country (2.08 billion liters) [9]. São Paulo State presented a production superior to 1.5 billion liters in 2007, corresponding to $34 \%$ of the total in the country, followed by the states of Rio de Janeiro (7\%) and Minas Gerais (6\%) [9]. In general terms, circa 20 million consumers are involved [10].

The major hydromineral spas at São Paulo (SP) State are situated at the following cities: Águas de Lindóia, Águas de Santa Bárbara, Águas de São Pedro, Águas da Prata, Amparo, Atibaia, Ibirá, Campos do Jordão, Monte Alegre do Sul, Nuporanga, Serra Negra and Socorro [11]. The number is also expressive at Minas Gerais (MG) State, where the main occurrences are at São Lourenço, Caxambu, Cambuquira, Lambari, Poços de Caldas, Conceição do Rio Verde and Araxá cities. All they exhibit good touristic infra-structure and mineral waters of different types, where some of them will be focused in this paper.

Many mineral springs in Brazil and elsewhere do not contain strong concentrations of constituents and are classified as lightly mineralized or oligomineral waters [12], thus, requesting special attention to possible anthropogenic inputs able to modify the drinking water quality, with implications to their bottling. This paper describes a comparative hydrochemical study of well-known Brazilian mineral bottled waters and of a spring occurring at Corumbataí city, São Paulo State, in order to evaluate its suitability for bottling.

\section{The Brazilian Code of Mineral Waters (BCMW)}

According to chemical aspects, the BCMW establishes the following water classification:

-Radiferous: contain dissolved radioactive substances that sustain a permanent radioactivity;

-Bicarbonate-alkaline: contain dissolved alkaline compounds corresponding to a minimum of $0.2 \mathrm{~g}$ per liter of sodium bicarbonate;

-Earth-alkaline: contain dissolved earth-alkaline compounds corresponding to a minimum of $0.12 \mathrm{~g}$ per liter of sodium carbonate. They may be Ca-dominated if contain at least $0.048 \mathrm{~g}$ per liter of $\mathrm{Ca}$ as calcium bicarbonate or $\mathrm{Mg}$-dominated if contain at least $0.030 \mathrm{~g}$ per liter of $\mathrm{Mg}$ as magnesium bicarbonate.

-Sulfated: contain dissolved sulfate corresponding to a minimum of $0.1 \mathrm{~g}$ per liter combined with sodium, potassium and magnesium;

-Sulphured: contain dissolved sulphur corresponding to a minimum of $0.001 \mathrm{~g}$ per liter;

-Nitrated: contain dissolved nitrate of mineral origin corresponding to a minimum of $0.1 \mathrm{~g}$ per liter;

-Chlorinated: contain dissolved chloride corresponding to a minimum of $0.5 \mathrm{~g}$ per liter of sodium chloride;

-Ferruginous: contain dissolved iron corresponding to a minimum of $0.005 \mathrm{~g}$ per liter; 
-Radioactive: contain dissolved radon according to three different levels, i.e. (a) weakly radioactive (radon content between 5 and 10 Mache Unit per liter), (b) radioactive (radon content between 10 and 50 Mache Unit per liter) and (c) strongly radioactive (radon content higher than 50 Mache Unit per liter).

-Thoriferous: contain dissolved thoron corresponding to a minimum of 2 Mache Unit per liter;

-Carbogaseous: contain dissolved carbon dioxide gas corresponding to a minimum of $200 \mathrm{~mL}$ per liter at $20^{\circ} \mathrm{C}$ temperature and $760 \mathrm{mmHg}$ pressure.

Brazilian mineral waters are also classified according to the temperature as follows [2]:

-Cold waters: temperature lower than $25^{\circ} \mathrm{C}$;

-Hypothermal waters: temperatures ranging from 25 to $33^{\circ} \mathrm{C}$;

-Mesothermal waters: temperatures ranging from 33 to $36^{\circ} \mathrm{C}$;

-Isothermal waters: temperatures ranging from 36 to $38^{\circ} \mathrm{C}$;

-Hyperthermal waters: temperature higher than $38^{\circ} \mathrm{C}$.

\section{Analytical methods}

The water samples $(\sim 5 \mathrm{~kg})$ for this study were stored in polyethylene bottles and, depending on the requirements of the analyzes, they were separated as unfiltered and unpreserved, filtered through $0.45 \mu \mathrm{m}$ membranes and preserved with different acids, etc. Several standard analytical techniques were utilized, for instance, dilution and incubation method, evaporation, methyl orange end-point titration, potentiometry, ion selective electrode, colorimetry, flame photometry and inductively-coupled plasma spectrometry. Portable meters were used for in situ determinations of temperature and dissolved oxygen (DO) in the spring water sample collected at Corumbataí city.

The $\mathrm{pH}$ measurement was performed by a digital portable meter coupled to a combination glass electrode, whereas a bench digital meter provided electrical conductivity readings obtained though a $1 \mathrm{~cm}^{2}$ area platinum electrode calibrated with $\mathrm{KCl}$ standards. The settleable solids were evaluated by a clear borosilicate glass Imhoff cone 0-1000 mL calibrated. The dry residue (DR) ( total dissolved solids, TDS) content was determined on evaporating the filtrate to dryness in a weighed flask that was dried to constant weight at $180^{\circ} \mathrm{C}$, with the increase in flask weight representing DR [13].

The turbidity and true color were determined by colorimetry after filtering the suspended materials and using a program stored in the Hach DR/2000 spectrophotometer that was calibrated in color units based on the APHArecommended standard of 1 color unit being equal to $1 \mathrm{mg} \mathrm{L}^{-1} \mathrm{Pt}$ as chloroplatinate ion [14]. The alkalinity was measured by titration using a titrator with sulfuric acid standard solution to an end point evidenced by the color change of a standard indicator solution [14]. The obtained values corresponded to alkalinity due to the presence of bicarbonate, carbonate and/or hydroxides. 
The spring water sample collected at Corumbataí city was submitted to total bacteria count consisting on the number of bacteria that can grow and form countable colonies on Standard Methods Agar after being held at $32^{\circ} \mathrm{C}$ for 48 hours. It was also analyzed for fecal and total coliforms through the fast ColiQuik Presence/Absence test that utilizes medium providing specific substrates, i.e. ONPG (o-nitrophenyl- $\beta$-d-galactopyranoside) and MUG (4methylumbelliferyl- $\beta$-d-glucuronide) [13]. Additionally, BOD (Biochemical Oxygen Demand) was characterized by the dilution method employing high purity distilled water provided by Barnstead Mega-Pure One Liter Water Still and COD (Chemical Oxygen Demand) through the dichromate reflux method using aliquots acidified to $\mathrm{pH}=2$ with concentrated $\mathrm{H}_{2} \mathrm{SO}_{4}$ [13].

Calcium hardness (as $\mathrm{CaCO}_{3}$ ) and magnesium hardness (as $\mathrm{MgCO}_{3}$ ) of the water samples were determined by the colorimetric method (wavelength $522 \mathrm{~nm}$ ) after chelating calcium with EGTA and calcium and magnesium with EDTA [14]. The analyses of dissolved sodium were done by flame photometry, whereas potassium was determined by the tetraphenylborate method that is based on the combination of $\mathrm{K}$ with sodium tetraphenylborate to form an insoluble white solid read at $650 \mathrm{~nm}$ by a program stored in Hach DR/2000 spectrophotometer. Nitrate and sulfate were also determined by colorimetry after adding others reagents for producing colored complexes [14].

Chloride and fluoride were measured potentiometrically after adding a known amount of ionic strength adjustor to each sample. The silicon, boron, phosphorous and metals $\mathrm{Al}, \mathrm{Ba}, \mathrm{Cr}, \mathrm{Cu}, \mathrm{Cd}, \mathrm{Fe}, \mathrm{Mn}, \mathrm{Pb}, \mathrm{Sn}, \mathrm{Zn}$ and Ti were quantified by inductively-coupled plasma spectrometry.

\section{The selected water samples for the comparative study}

Seven bottled mineral water samples were taken for analysis, which provide from the following cities at São Paulo State: Serra Negra, Poá, Ipeúna, Monte Alegre do Sul, Campos do Jordão, Águas da Prata and Águas de Lindóia. Their major characteristics are described in Tables 1 and 2.

The spring sample for hydrochemical comparison was collected at Santo Antonio farm, Corumbataí municipality, situated at $22^{\circ} 13^{\prime} 13^{\prime \prime} \mathrm{S}$ and $47^{\circ} 37^{\prime} 32^{\prime \prime} \mathrm{W}$ in São Paulo State. It is inserted within the geological context of the Paraná sedimentary basin that constitutes a geotectonic unit established over the South American Platform since the Lower Devonian or Silurian [15]. The spring discharge occurs through sediments of the Corumbataí Formation that have been deposited in the Upper Permian and belong to Passa Dois Group together with Irati, Serra Alta, Teresina and Rio do Rasto Formations [15]. The Passa Dois Group sediments consist on: siltstones, claystones and silty shales of clear to dark gray color, bituminous shales locally alternating with silicified fawnish limestones and restrict conglomeratic levels; essentially marine deposits including siltstones, shales and dark gray to black claystones with plane-parallel lamination; marine deposits comprising shales and dark gray to greenish/reddish finely laminated claystones alternating with siltstones and very fine sandstones in the presence of restrict lenses of oolitic limestones and silex; coastal plain 
deposits including very fine to mean greenish/reddish sandstones and subordinated claystones and reddish siltstones; possibly tidal plains marine deposits, including claystones, shales and gray, reddish or purplish siltstones with intercalations of carbonatic benches and layers of fine sandstones [15].

Table 1: $\quad$ Major features of the bottled mineral waters studied in this paper.

\begin{tabular}{|c|c|c|c|c|}
\hline Sample No. & 1 & 2 & 3 & 4 \\
\hline $\begin{array}{c}\text { Commercial } \\
\text { name }\end{array}$ & Serra Negra & Poá & Cantagalo & $\begin{array}{c}\text { Camanduca } \\
\text { ia }\end{array}$ \\
\hline Owner & Santa Helena & União & Mineradora & Spal- \\
\hline & - Empresa de & & Cantagalo & Indústria de \\
\hline & Mineral & $\begin{array}{l}\text { Espirita } \\
\text { Paulista }\end{array}$ & & $\begin{array}{l}\text { Defidas } \\
\text { S.A. }\end{array}$ \\
\hline Spring name & Cristalina & Áurea & Progresso & $\begin{array}{c}\text { Camanduca } \\
\text { ia }\end{array}$ \\
\hline City(State) & $\begin{array}{l}\text { Serra Negra } \\
\text { (SP) }\end{array}$ & Poá (SP) & Ipeúna (SP) & $\begin{array}{c}\text { Monte } \\
\text { Alegre do } \\
\text { Sul (SP) }\end{array}$ \\
\hline $\begin{array}{l}\text { Commercial } \\
\text { classification }\end{array}$ & $\begin{array}{l}\text { Slightly } \\
\text { radioactive }\end{array}$ & $\begin{array}{l}\text { Fluoridated and } \\
\text { radioactive }\end{array}$ & Fluoridated & Radioactive \\
\hline Temp. $\left({ }^{\circ} \mathrm{C}\right)$ & 21 & 21 & 21 & 21 \\
\hline $\mathrm{pH}$ & 5.6 & 4.8 & 5.2 & 5.7 \\
\hline $\begin{array}{l}\text { Conductivity } \\
(\mu \mathrm{S} / \mathrm{cm})\end{array}$ & 50 & 63 & 84 & 39.1 \\
\hline $\begin{array}{l}\text { Dry residue } \\
(\mathrm{mg} / \mathrm{L})\end{array}$ & 52 & 30 & 57 & 36 \\
\hline $\begin{array}{l}\text { Radioactivity } \\
(\mathrm{MU})^{1}\end{array}$ & 7.9 & 21.8 & - & 12.3 \\
\hline $\mathrm{BaSO}_{4}(\mathrm{mg} / \mathrm{L})$ & - & 0.02 & - & - \\
\hline $\mathrm{CaSO}_{4}(\mathrm{mg} / \mathrm{L})$ & - & 1.97 & 6.33 & - \\
\hline $\mathrm{SrSO}_{4}(\mathrm{mg} / \mathrm{L})$ & - & - & 0.04 & - \\
\hline $\begin{array}{c}\mathrm{Ca}\left(\mathrm{HCO}_{3}\right)_{2} \\
(\mathrm{mg} / \mathrm{L})\end{array}$ & 13.14 & 5.74 & 17.59 & 6.71 \\
\hline$\underset{(\mathrm{mg} / \mathrm{L})}{\mathrm{Mg}\left(\mathrm{HCO}_{3}\right)_{2}}$ & 6.26 & - & 18.23 & 3.01 \\
\hline $\mathrm{KHCO}_{3}(\mathrm{mg} / \mathrm{L})$ & 5.12 & 5.89 & 4.61 & 5.07 \\
\hline $\mathrm{NaHCO}_{3}(\mathrm{mg} / \mathrm{L})$ & 12.57 & 5.64 & 7.90 & - \\
\hline $\mathrm{NaNO}_{3}(\mathrm{mg} / \mathrm{L})$ & 8.59 & 5.52 & - & 4.76 \\
\hline $\mathrm{KNO}_{3}(\mathrm{mg} / \mathrm{L})$ & - & - & - & 0.05 \\
\hline $\mathrm{NaCl}(\mathrm{mg} / \mathrm{L})$ & 2.62 & 4.78 & 2.85 & 1.68 \\
\hline $\mathrm{NaF}(\mathrm{mg} / \mathrm{L})$ & - & 0.16 & 0.22 & - \\
\hline $\begin{array}{l}\mathrm{Sr}\left(\mathrm{HCO}_{3}\right)_{2} \\
(\mathrm{mg} / \mathrm{L})\end{array}$ & 0.09 & - & - & 0.05 \\
\hline $\begin{array}{c}\mathrm{Ba}\left(\mathrm{HCO}_{3}\right)_{2} \\
(\mathrm{mg} / \mathrm{L})\end{array}$ & 0.19 & - & - & 0.19 \\
\hline
\end{tabular}


Table 2: $\quad$ Major features of the bottled mineral waters studied in this paper.

\begin{tabular}{|c|c|c|c|}
\hline Sample No. & 5 & 6 & 7 \\
\hline Commercial name & Minalba & Prata & Lindóia \\
\hline Owner & Minalba Alimentos e & Empresa das & Ãgua de Lindóia \\
\hline & Bebidas Ltda. & $\begin{array}{l}\text { Águas Prata } \\
\text { S.A. }\end{array}$ & $\begin{array}{c}\text { Mineração } \\
\text { Comércio Ltda. }\end{array}$ \\
\hline Spring name & Água Santa & Leve II & Lindália \\
\hline City (State) & $\begin{array}{c}\text { Campos do Jordão } \\
\text { (SP) }\end{array}$ & $\begin{array}{l}\text { Águas da Prata } \\
\text { (SP) }\end{array}$ & $\begin{array}{l}\text { Águas de Lindóia } \\
\text { (SP) }\end{array}$ \\
\hline $\begin{array}{l}\text { Commercial } \\
\text { classification }\end{array}$ & Radioactive & $\begin{array}{l}\text { Fluoridated and } \\
\text { radioactive }\end{array}$ & Radioactive \\
\hline Temp. $\left({ }^{\circ} \mathrm{C}\right)$ & 18 & 22 & 21 \\
\hline $\mathrm{pH}$ & 7.8 & 6.5 & 6.0 \\
\hline $\begin{array}{l}\text { Conductivity } \\
(\mu \mathrm{S} / \mathrm{cm})\end{array}$ & 145 & 200 & 73.8 \\
\hline $\begin{array}{l}\text { Dry residue } \\
(\mathrm{mg} / \mathrm{L})\end{array}$ & 85 & 142 & 92 \\
\hline $\begin{array}{l}\text { Radioactivity } \\
\text { (MU) }{ }^{1}\end{array}$ & 15.6 & 33.9 & 10.1 \\
\hline $\mathrm{BaSO}_{4}(\mathrm{mg} / \mathrm{L})$ & - & 0.36 & - \\
\hline $\mathrm{CaSO}_{4}(\mathrm{mg} / \mathrm{L})$ & - & 5.94 & - \\
\hline $\mathrm{SrSO}_{4}(\mathrm{mg} / \mathrm{L})$ & 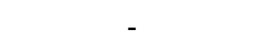 & 0.38 & - \\
\hline $\mathrm{Ca}\left(\mathrm{HCO}_{3}\right)_{2}(\mathrm{mg} / \mathrm{L})$ & 66.33 & 79.64 & 18.60 \\
\hline $\mathrm{Mg}\left(\mathrm{HCO}_{3}\right)_{2}(\mathrm{mg} / \mathrm{L})$ & 50.18 & 57.04 & 12.39 \\
\hline $\mathrm{KHCO}_{3}(\mathrm{mg} / \mathrm{L})$ & 2.05 & 9.09 & 5.12 \\
\hline $\mathrm{NaHCO}_{3}(\mathrm{mg} / \mathrm{L})$ & 3.04 & 1.07 & 9.62 \\
\hline $\mathrm{NaNO}_{3}(\mathrm{mg} / \mathrm{L})$ & 0.82 & 3.49 & 8.22 \\
\hline $\mathrm{KNO}_{3}(\mathrm{mg} / \mathrm{L})$ & - & - & - \\
\hline $\mathrm{NaCl}(\mathrm{mg} / \mathrm{L})$ & 0.35 & 2.57 & 7.70 \\
\hline $\mathrm{NaF}(\mathrm{mg} / \mathrm{L})$ & - & 0.40 & - \\
\hline $\mathrm{Sr}\left(\mathrm{HCO}_{3}\right)_{2}(\mathrm{mg} / \mathrm{L})$ & 0.03 & - & 0.09 \\
\hline $\mathrm{Ba}\left(\mathrm{HCO}_{3}\right)_{2}(\mathrm{mg} / \mathrm{L})$ & 0.38 & - & 0.09 \\
\hline
\end{tabular}

\section{Results and discussion}

The results obtained for the analyzed samples are reported in Table 3 and compared with guideline values established by the BCMW and Register 25 of the National Commission of Rules and Standards for Food of the Brazilian Health Ministry published on 1976 (Table 4).

The data for major ions in all samples were plotted on a Piper [16] diagram. Fig. 1 shows that except Poá (sample 2) and Camanducaia (sample 4) springs, all waters are bicarbonated and mixed in terms of major cations.

Only Mn in mineral water Poá (sample 2) exceeded the reference value of $0.05 \mathrm{mg} / \mathrm{L}$ (Table 3), among the constituents analyzed in samples 1-7. Additionally, the spring water sample collected at Corumbataí city exhibited constraints on the related microbiological parameters COD, total coliforms and bacteria counting (Table 2), implying on restrictions for bottling and 


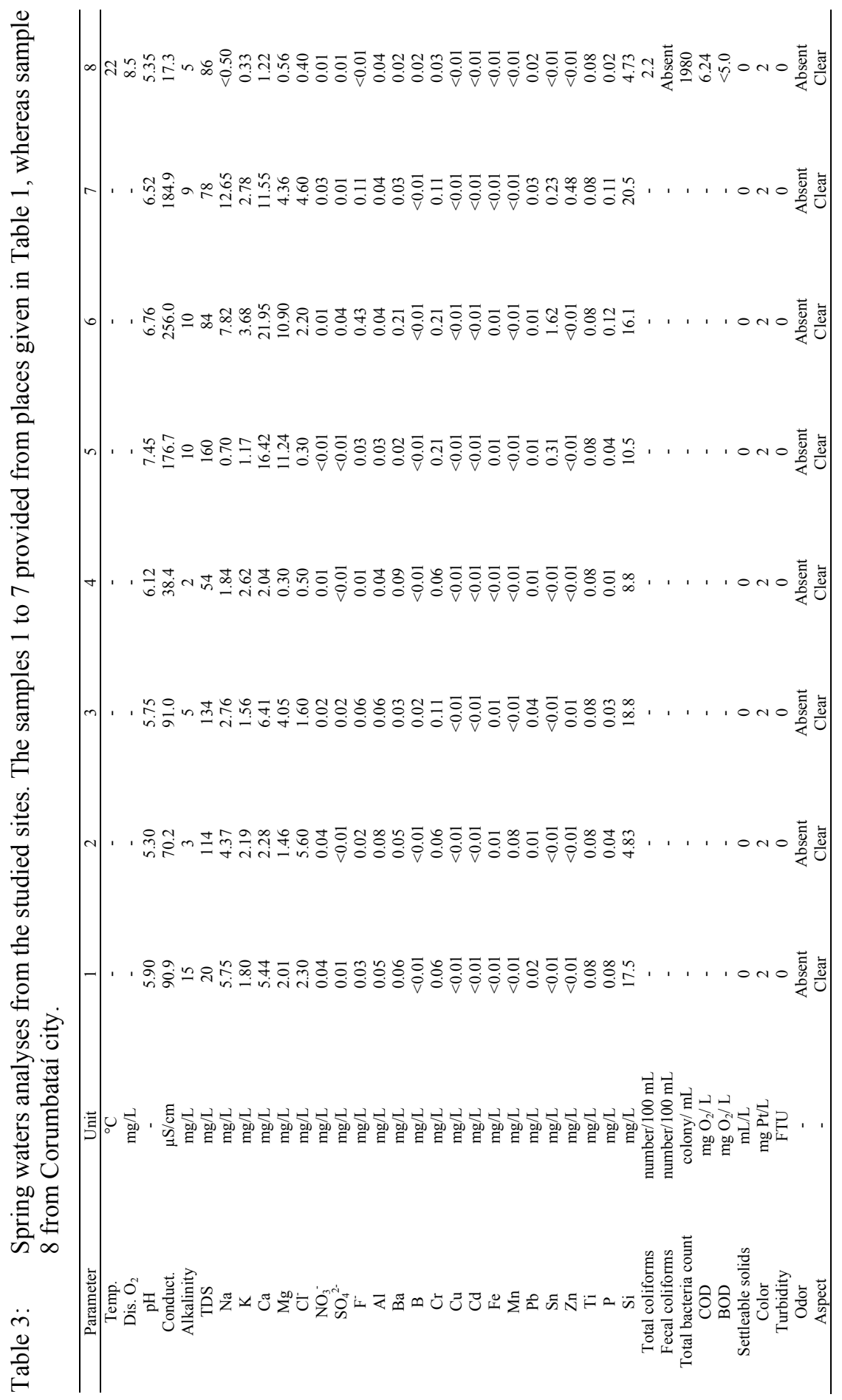


consumption. But it could be chemically treated (i.e. by chlorination) for drinking purposes, under which circumstance the classification "of natural spring" would not be pertinent for commercialization.

Table 4: Guideline values established by register 25 of the national commission of rules and standards for food of the Brazilian health ministry published on 1976.

\begin{tabular}{ccc}
\hline PARAMETER & UNIT & VALUE \\
\hline Aspect & - & clear \\
Color & $\mathrm{mg} \mathrm{Pt} / \mathrm{L}$ & $<5$ \\
Odor & - & absent \\
Turbidity & $\mathrm{FTU}$ & 3 \\
COD & $\mathrm{mg} / \mathrm{L}$ & 4.5 \\
pH & $\mathrm{mg} / \mathrm{L}$ & $<1500$ \\
Total Dissolved Solids $(\sim \mathrm{DR})$ & - & between 4 and 9 \\
Alkalinity - hydroxides & - & 0 \\
Chloride & $\mathrm{mg} / \mathrm{L}$ & 100 \\
Fluoride & $\mathrm{mg} / \mathrm{L}$ & 1 \\
Zinc & $\mathrm{mg} / \mathrm{L}$ & $<5$ \\
Cadmium & $\mathrm{mg} / \mathrm{L}$ & 0.01 \\
Lead & $\mathrm{mg} / \mathrm{L}$ & 0.05 \\
Copper & $\mathrm{mg} / \mathrm{L}$ & 1 \\
Barium & $\mathrm{mg} / \mathrm{L}$ & 1 \\
Manganese & $\mathrm{mg} / \mathrm{L}$ & 0.05 \\
Chromium & $\mathrm{mg} / \mathrm{L}$ & 0.05 \\
\hline & &
\end{tabular}

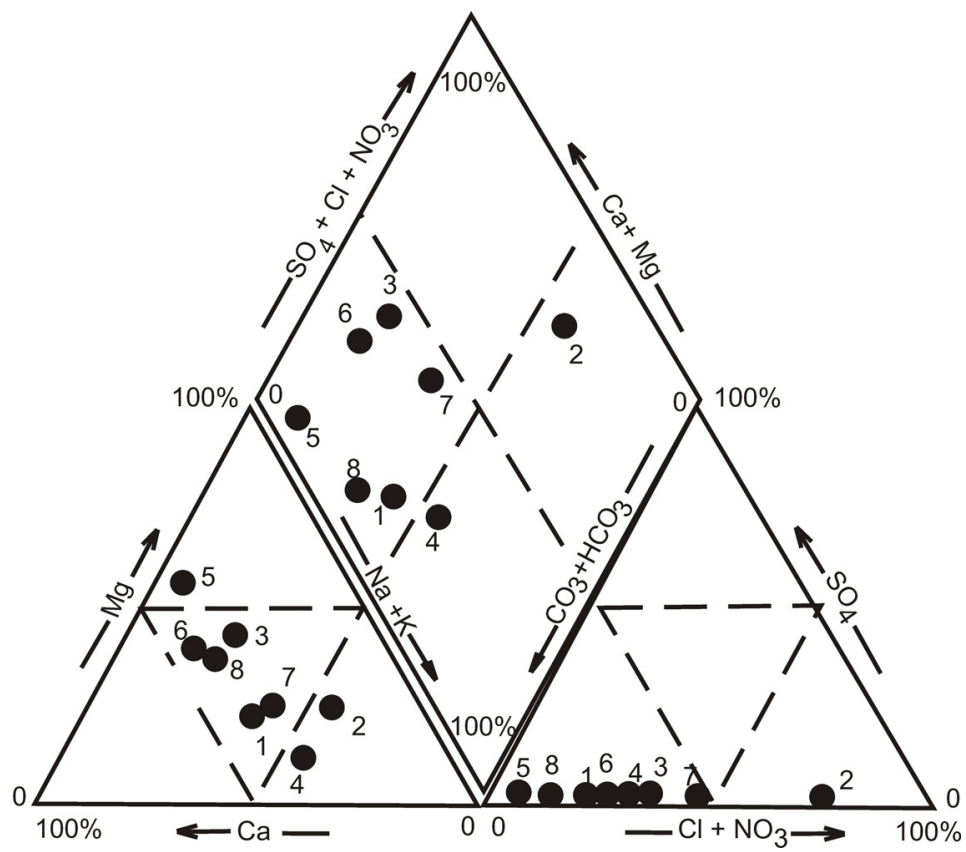

Figure 1: Major chemical data of the spring waters plotted on a Piper diagram. 
The comparison of data reported in Table 2 with the BCMW indicates that Minalba (sample 5) and Prata (sample 6) springs possess values exceeding the minimum established by the BCMW for calcium bicarbonate $(48 \mathrm{mg} / \mathrm{L})$ and magnesium bicarbonate $(30 \mathrm{mg} / \mathrm{L})$ and, therefore, could be considered "mineral waters".

Fluoride is a trace constituent relatively abundant in Prata spring (sample 6), justifying its classification "fluoridated". The same did not occur for Poá (sample 2) and Cantagalo (sample 3) springs, whose fluoride content was low, contrarily to Lindóia spring (sample 7).

It is interesting verify that the radioactivity property is widely used for classifying all mineral waters, except Cantagalo spring (sample 3). However, it may be also radioactive as no radon analysis has been reported (Table 1).

The owners of the land where outcrops the spring water sampled at Corumbataí city intended to bottle the water for human consumption and classify it as mineral. They inclusive provided some logistical support for performing analyzes of others mineral waters with the aim of a comparative evaluation of their major features. However, the analytical results of this study clearly indicated that the source is not suitable for drinking purposes, unless previous chemical treatment is realized. On the other hand, this is an undesirable situation under the economic point of view, as restrictions exist in the mineral water market.

Another highlight of this study is related to the fact that the bottling of mineral waters is a relevant economic activity in Brazil. However, the BCMW is an ancient legislation that has not been modified for accompanying the accentuated development of the sector. There are some incongruent aspects that must be properly addressed, mainly in order to fit the international standards.

Under this view, the property of radioactivity should be taken into account as now considered. The first major aspect is related to the unit adopted for the waters classification based on radioactivity. Mache reported in 1904 and 1905 the presence of radioactivity in waters occurring in Austria and Jáchymov, today Czech Republic [17-19], discovery that allowed the installation of spas in some sites. Mache also introduced one unit for expressing the radon activity, which was later named Mache Unit (MU), commonly used in Austrian and German literature. But most of others countries preferred to adopt "Curie" rather than MU for expressing the radioactivity, following recommendations proposed in the Second Congress of Radiology realized in 1910 at Brussels [20]. The correspondence between them is: $1 \mathrm{MU}=364 \mathrm{pCi} / \mathrm{L}$, or $1000 \mathrm{pCi} / \mathrm{L}=2.75 \mathrm{MU}$ [21]. In terms of Brazil, spas had much developed in the early 1900s, many of them suffering influence of German immigrants. Therefore, such an aspect could at least partially justify the introduction of the MU in the BCMW that has not been modified by historical, political and economic reasons.

Another aspect of the BCMW concerns to the adoption of radon for classifying mineral waters. Radon $\left({ }^{222} \mathrm{Rn}\right.$, half-life 3.84 days $)$ is a colorless, odorless, tasteless, chemically inert and radioactive volatile noble gas produced continuously in rocks and soils through $\alpha$-decay of ${ }^{226} \mathrm{Ra}$, with some atoms escaping to the surrounding fluid phase, such as groundwater and air. Its 
characterization in waters is important because it may be utilized as an isotopic tracer in hydrologic investigations and also in order to assure the drinking water quality, since although radon in water is not a well-documented health risk, it does contribute to radon in indoor air, which has been established as a health threat [22]. WHO defined guidance levels in drinking water for ${ }^{238} \mathrm{U}$ and daughters like ${ }^{234} \mathrm{U},{ }^{230} \mathrm{Th},{ }^{226} \mathrm{Ra},{ }^{222} \mathrm{Rn},{ }^{210} \mathrm{~Pb}$, and ${ }^{210} \mathrm{Po}$, whose activity concentration evaluation involves sophisticated and time-consuming procedures and are generally performed if the gross alpha and beta measurements have exceeded 0.5 and $1 \mathrm{~Bq} / \mathrm{L}$, respectively [23]. In terms of ${ }^{222} \mathrm{Rn}$, WHO proposed that controls should be implemented if the ${ }^{222} \mathrm{Rn}$ concentration of drinking-water for public water supplies exceeds $100 \mathrm{~Bq} / \mathrm{L}$, i.e. treatment of the water source should be undertaken to reduce the ${ }^{222} \mathrm{Rn}$ levels to well below $100 \mathrm{~Bq} / \mathrm{L}$ [23].

It is evident that the BCMW does not take into account the WHO recommendations concerning to the radon ingestion in waters as, in principle, population would be able to ingest strongly radioactive mineral waters containing radon content higher than $50 \mathrm{MU}$ per liter. Despite the data reported in Table 2 for bottled mineral waters studied in this paper do not indicate such high levels, they are sometimes verified for waters consumed by users. Therefore, decision makers and people engaged in the proper management of the mineral waters in Brazil should direct efforts for adjusting the guidelines of the BCMW in order to reach the international standards, what certainly is a task involving conflicts with different segments of the society.

\section{Acknowledgement}

CNPq (National Council for Scientific and Technologic Development) in Brazil is thanked for financial support of this investigation.

\section{References}

[1] Gonsalves, A.D., Aguas Mineraes do Brasil. Ministério da Agricultura: Rio de Janeiro, 1936.

[2] Marras, S., A propósito de Águas Virtuosas. Formação e Ocorrências de uma Estação Balneária no Brasil. UFMG: Belo Horizonte, 2004.

[3] Ottoni, H.B., Poços de Caldas. Anhambi: São Paulo, 1960.

[4] Serra, S.H., Águas minerais do Brasil. Millenium Editora: Campinas, 272 pp., 2009.

[5] Mourão, B.M., A água mineral e as termas - uma história milenar. ABINAM: São Paulo, 1997.

[6] Andrade Júnior, J.F. Boletim do Serviço Geológico e Mineralógico do Brasil. Ministério da Agricultura, Indústria e Comércio: Rio de Janeiro, 1928.

[7] Mourão, B.M., Medicina hidrológica - moderna terapêutica das águas minerais e estâncias de cura. Secretaria Municipal de Educação: Poços de Caldas, 1992. 
[8] DFPM (Division for Supporting the Mineral Production), The mining code, the mineral waters code and how applying research in a mineral deposit. $8^{\text {th }}$ edn., DFPM: Rio de Janeiro, 1966.

[9] A indústria brasileira de água mineral; CPRM (Serviço Geológico do Brasil), Online. http://www.cprm.gov.br/

[10] Comércio de água mineral; SEBRAE, Online. www.sebraesc.com.br/ideais/default.asp?vcdtexto $=31586 \& \% 5 \mathrm{E} \% 5 \mathrm{E}$

[11] Estâncias hidrominerais; Portal do Governo do Estado de São Paulo. Online. $\quad$ http://www.saopaulo.sp.gov.br/conhecasp/turismo estanciashidrominerais

[12] Altman, N., Healing springs, Healing Arts Press: Rochester, 2000.

[13] APHA (American Public Health Association), Standard methods for the examination of water and wastewater. $17^{\text {th }}$ edn, Washington, 1989.

[14] HACH, Water Analysis Handbook, $2^{\text {nd }}$ edn., Hach Company: Loveland, 1992.

[15] Almeida, F.F.M. and Melo, M.S., A bacia do Paraná e o vulcanismo Mesozóico. Mapa geológico do estado de São Paulo, ed. IPT (Instituto de Pesquisas Tecnológicas do Estado de São Paulo), Promocet: São Paulo, v. 1, pp. 46-81, 1981.

[16] Piper, A.M., A graphic procedure in the geochemical interpretation of water-analyses. Eos Trans. AGU, 25, pp. 914-928, 1944.

[17] Mache, H., Über die im Gasteiner Wasser enthaltene radioaktive Emanation. Physikal. Zeitschrift, 5/15, pp. 441-444, 1904.

[18] Mache, H., Über die Radioaktivität der Gasteiner Thermen. Wiener Sitz.ber. Akad. d. Wiss., 113, pp. 1329-1352, 1904.

[19] Mache, H. and Meyer, S., Über die Radioaktivität der Quellen der böhmischen Bädergruppe: Karsbad, Marienbad, Teplitz-Schönau-Dux, Franzensbad sowie von St. Joachimsthal. Aus den Sitzungsbereichten der kaiserl. Akademie der Wissenschaften in Wien. Mathem.-Naturw. Klasse. 114. Abt. II.a. Wien, 1905.

[20] Falcão, H., Perfil analítico de águas minerais. DNPM (Departamento Nacional de Produção Mineral): Rio de Janeiro, Bol. 49, v. 2, 160 pp., 1978.

[21] Becker, K., One century of radon therapy. International Journal of Low Radiation, 1, pp. 333-357, 2004.

[22] Nazaroff, W.W. and Nero Jr., A.V., Radon and its decay products in indoor air. Wiley: New York, 1988.

[23] WHO (World Health Organization), Guidelines for drinking water quality. $3^{\text {rd }}$ edn. WHO Press: Geneva, 2008. 